\title{
JUURNAL.RU
}

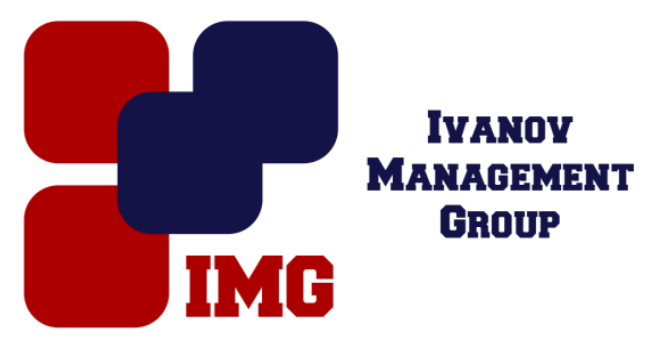

Павловский В.С.

Институт законодательства и сравнительного правоведения при Правительстве Российской Федераичи Москва, Россия

doi: $10.18411 / \mathrm{lj}-31-07-2017-45$

idsp 000001:1j-31-07-2017-45

\section{Становление австралийского мультикультурализма: исторические и правовые особенности}

\section{Аннотация}

В статье оценивается австралийский опыт идеологического обоснования и правового установления мультикультурализма в качестве основы государственной национальной политики. После официального утверждения мультикультурализма в качестве государственной политики в Австралии были созданы, а после не раз реформировались государственные органы, ответственные за его поддержание и развитие. Однако пример Австралии показывает, что условием успешного проведения политики мультикультурализма являются не только своевременные и эффективные государственные усилия, но и зрелость гражданского общества, заинтересованность населения страны в признании культурного разнообразия и сохранении этнокультурных традиций.

Ключевые слова: мультикультурализм, государственная национальная политика, идентичность, адаптация, разнообразие.

\section{Abstract}

The article discusses the Australian experience of the ideological and legal establishment as a basis of the State's National Policy. After multiculturalism was legally confirmed as a basis of the State's National Policy in Australia, the responsible state authorities were established to support the implementation of multiculturalism into the Canadian society. Obviously, there is not one proper approach on 
multiculturalism which has provided good results for all countries. However, the Australian multiculturalism experience is extremely valuable in the modern world since it shows what legal tools modern countries could use to fight discrimination and intolerance. However, the idea of multiculturalism could only be effective if it finds legal approval and social understanding.

Keywords: multiculturalism, state national policy, identity, adaptation, diversity.

Практически любое современное общество представляет собой смешение и взаимодействие различных культур, традиций, языков, религий и верований. В таких условиях установление и поддержание добрососедских отношений и уменьшение межнациональных противоречий становится сложной задачей. Для решения этой задачи требуются значительные государственные и общественные усилия в экономической, социальной, культурной, образовательной и других сферах. Законодательная область тут, может быть, и не самая главная. Но и приуменьшать значение права в этих процессах недопустимо. Право как один из сильнейших регуляторов общественных отношений призвано установить и поддерживать в стране равные возможности для всех граждан, независимо от их национальной принадлежности, и, кроме того, обеспечить сохранение традиций и обычаев малых народов, которые без такой помощи рискуют столкнуться с угрозой утраты своей исторической самобытности. Игнорирование или половинчатое решение этих вопросов ведут к нарушению общественного согласия, проявлениям негативного национализма и экстремизма, увеличению числа иммигрантов, вынужденных покинуть родную страну в поисках стабильности и защищённости за рубежом. Задача науки конституционного права в предотвращении подобного сценария. В этой связи актуально проведение исследований опыта различных государств по правовому регулированию вопросов национальной политики.

Современные государства стремятся осуществлять правовое регулирование проводимой ими национальной политики, не ограничиваясь только документами стратегического планирования или программными заявлениями политических деятелей. Право - действенный инструмент по предотвращению возможного возникновения межнациональных конфликтов и дискриминации. Оно способствует поддержанию многообразия и, в конечном итоге, превращению разнообразия общества не в проблему, а в преимущество. По этому пути сегодня идёт большое число многонациональных государств - 
США, Канада, Новая Зеландия, Бельгия, Франция и др. Однако можно с уверенностью утверждать, что наиболее впечатляющих успехов в поддержании и развитии национального и культурного многообразия в сочетании с экономическим процветанием на сегодняшний день достигла Австралия.

Австралии удалось достичь баланса между грамотным правовым регулированием вопросов национальной политики, её идеологическим обоснованием и свободной инициативой её субъектов. Основой национальной политики Австралии является мультикультурализм, главная идея которого базируется на том основании, что все культуры представляют собой в равной степени правомерные жизненные модели: каждая из них самодостаточна, автономна, отдельна от других, но в то же время равна всем другим. Австралийский опыт мультикультурализма, в принципе, имеет некоторые общие черты с мультикультурализмом Канады. И Австралия, и Канада некогда испытывали на себе сильное влияние Великобритании, обе страны были вынуждены вести особую иммиграционную политику для решения демографических проблем и заселения обширных территорий. В Австралии, как и в Канаде, политика мультикультурализма выросла из иммиграционной политики, которая до 70-х гг. XX в. носила ограничительный характер. До середины XX в. Австралия придерживалась политики «Белой Австралии», при которой иммиграция рассматривалась как приемлемая для нации только в том случае, если она ограничивалась белыми европейцами, предпочтительно англосаксами.

Превалирующим в австралийской иммиграционной политике вплоть до окончания Второй мировой войны являлся подход ассимиляции. Считалось, что иммигранты должны постепенно самостоятельно отказываться от своей культуры и языка и в кратчайшие сроки сливаться с культурой принимающей страны. Кроме того, по прибытии в Австралию на помощь со стороны государства могли рассчитывать только переселенцы из Великобритании: им компенсировались затраты на переезд, оказывалось содействие в обеспечении занятости и решении жилищных вопросов. Конечно, иммиграция не ограничивалась только выходцами из Северной и Центральной Европы. Но, например, иммиграция представителей стран Восточной и Южной Европы была сопряжена с некоторыми ограничениями, которые имели тенденцию к ужесточению в случае ухудшения в Австралии экономической ситуации и, напротив, к смягчению при повышении спроса на рабочую силу. А для лиц 
неевропейского происхождения иммиграция была практически вовсе исключена.

Качественное переосмысление подходов к осуществлению государственной национальной политики в Австралии произошло после Второй мировой войны. Политика «Белой Австралии» была широко осуждена федеральным Правительством. Страна столкнулась с серьёзной демографической проблемой (население в тот момент исчислялось всего 7 млн. человек), решать которую нужно было немедленно. В 1947 г. австралийское Правительство открыло программу стимулирования иммиграции, которая проходила под бескомпромиссным лозунгом «Заселить или погибнуть». Были отменены все ограничения на иммиграцию из стран Европы, в том числе и для людей, не владеющих английским языком. В 1948 г. был принят Закон о гражданстве Австралии. Этот Закон стал шагом вперёд по сравнению с аналогичным европейским законодательством, поскольку в качестве главного условия приобретения гражданства был выбран пятилетний срок проживания в стране. Приток иммигрантов в Австралию увеличился, причём настолько, что правительственные круги и крупные коммерсанты уже не были свободны в проектировании и осуществлении национальной политики только на основании экономических перспектив. Существенное влияние на формирование государственной национальной политики оказывали разнообразные общественные объединения, отстаивавшие интересы этнических меньшинств. Они активно выступали с требованиями об увеличении числа разрешений на въезд по линии воссоединения семей. Эти требования шли вразрез с экономически детерминированными целями иммиграционных программ, направленных на привлечение в страну только квалифицированной рабочей силы.

Официально поворот в сторону мультикультурализма в Австралии произошёл в 1973 г., когда «отец австралийского мультикультурализма» министр по делам иммиграции Эл Гразби (Al Grassby) выступил против ассимиляционного подхода к иммигрантам, присущего прежним этапам национальной политики Австралии. В своём программном обращении «Будущее за мультикультурным обществом» (A Multi-cultural Society for the Future) он настаивал на признании положительного вклада иммигрантов в развитие Австралии, а также изложил своё видение концепции мультикультурализма, которое состояло в обеспечении равенства возможностей, уважении достоинства и справедливом отношении ко всем членам общества. Это выступление 
ознаменовало конец политики «Белой Австралии», место которой было замещено новым видением австралийского общества - мультикультурализмом, направленным на поддержание этнических и расовых различий, а не на их подавление.

В 1975 г. в Австралии на основании международных обязательств, прежде всего, по Международной конвенции о ликвидации всех форм расовой дискриминации 1965 г., был принят Закон о запрете расовой дискриминации (Racial Discrimination Act), который имел огромное значение для развития австралийского мультикультурализма и продолжает действовать по сей день. Этот Закон был призван не только сделать дискриминацию в любых её проявлениях неприемлемой, но также и установить стандарт на будущее, содействовать «климату доброжелательности, гражданской зрелости, сотрудничества и взаимопонимания на всех уровнях общества». Тем не менее, по мнению ряда крупных австралийских учёных, эффект от действие Закона о запрете расовой дискриминации не вполне соответствует ожиданиям. Так, профессор права Бет Гейз (Beth Gaze) полагает, что «по любым оценкам Закон о запрете расовой дискриминации не воплотил своё символическое значение в жизнь. В основном, действие Закона показало, что это слабый инструмент в борьбе с расовой дискриминацией». Другой исследователь, Маргарет Торнтон (Margaret Thornton), констатируя крах «либеральных обещаний» Закона о запрете расовой дискриминации, описывает любые законодательные попытки ограничить дискриминацию как «атомизм». По её мнению, «право может быть полезным только в ликвидации последствий уже совершённых актов расовой дискриминации, но не в состоянии оказать влияние на саму проблему. Правовые средства не могут уничтожить атмосферу предубеждения и глубоко укоренившиеся социальные противоречия, которые являются основой дискриминации». Однако следует признать, что Закон о запрете расовой дискриминации стал не только символом построения мультикультурного общества, но также и практическим инструментом по защите прав австралийцев, подвергшихся дискриминации. С начала действия Закона в 1975 г. по 2015 г. австралийскими судами в более чем 6000 случаев были удовлетворены требования о защите от расовой дискриминации.

В 1977 г. при Правительстве Австралии был создан Совет по этническим делам (The Australian Ethnic Affairs Council), выполнявший консультативные функции. Совет высказал свои предложения по развитию государственной политики мультикультурализма в докладе «Австралия как мультикультурное 
общество» (Australia as a Multicultural Society). Основное внимание в докладе уделялось достижению социальной справедливости, формированию на её основе единой австралийской гражданской идентичности и созданию общества равных возможностей для представителей всех национальностей. В заключение отмечалось, что перед Австралией стоит задача по созданию общества, в котором людям без англо-австралийских корней будет предоставлена возможность сохранять и развивать, индивидуально или коллективно, их культуру - языки, традиции и искусство. Только так эти люди смогут стать живым элементом смешанной культуры общества, при этом имея возможность на равный доступ к правам и возможностям, которые этим обществом обеспечиваются. В докладе также отмечается, что неправильно было считать, будто мультикультурализм заключается в том, что каждая культура одинаково оценивается обществом и признаётся законом. Например, для австралийского общества совершенно неприемлема ситуация, при которой глава семьи вершит расправу над провинившимся членом семейства, подменяя собой закон, даже если такое поведение свойственно какой-либо культурной или религиозной традиции. Мультикультурализм же заключается в том, что представители каждой культуры должны иметь возможность заявить о своих требованиях, проблемах и предложениях, что они должны приниматься всерьёз как государственными органами, так и общественным мнением.

Последовала целая серия создания различных органов, имевших как научно-консультативный характер, так и обладавших конкретными полномочиями по выработке и реализации государственной национальной политики. В 1979 г. актом Парламента был учреждён Австралийский институт по делам мультикультурализма (Australian Institute on Multicultural Affairs), цели которого состояли в увеличении уровня осознания пользы культурного разнообразия и в содействии достижению социального согласия, взаимопонимания и толерантности. Однако в 1986 г. деятельность этого Института была прекращена. В 1987 г. в структуре Правительства Австралии было образовано Управление по делам мультикультурализма (Office of Multicultural Affairs). В 1996 г. Управление было поглощено Министерством по иммиграции и делам мультикультурализма (Department of Immigration and Multicultural Affairs).

С этого момента и вплоть до настоящего времени федеральное Правительство Австралии периодически делало программные заявления, которые оказывали значительное влияние на выработку основных направлений 
государственной национальной политики и их реализацию: «Мультикультурная Австралия: единство в разнообразии» (Multicultural Australia: United in Divesity) - 2003 г., «Народ Австралии» (The People of Australia) - 2011 г. Последний доклад был сделан марте 2017 г. и назывался «Мультикультурная Австралия: единая, сильная, успешная» (Multicultural Australia: united, strong, successful).

Этот доклад в значительной степени обращён не к государственным органам и общественным объединениям, а к простым людям. Он выполняет просветительскую функцию, напоминает гражданам о достижениях австралийского мультикультурализма, ставит задачи на ближайшие годы. В предисловии к докладу действующий Премьер-министр Австралии Малькольм Тернбулл (Malcolm Turnbull) отметил, что Австралия сумела построить самое успешное мультикультурное общество в мире. При этом в облике современного австралийца определяющими не являются ни национальность, ни культура, ни религия. В основу общества положены непреходящие ценности свободы, демократии, верховенства закона и равных возможностей. Это отражено и в тексте присяги, которую произносят иммигранты, получающее гражданство в порядке натурализации: «Я провозглашаю свою преданность Австралии и её народу, демократические ценности которого я разделяю, права и свободы которого я уважаю, законы которого я обязуюсь соблюдать». Новая программа в сфере мультикультурализма подтверждает приверженность Правительства Австралии идее мультикультурного общества, в котором нет места расизму и дискриминации.

Сегодня большинство австралийцев разделяют ценности мультикультурализма и положительно оценивают итоги проводимой государством политики по его развитию. Масштабный опрос общественного мнения, проведённый в 2015 г. показал, что 86 \% австралийцев согласны с тем, что мультикультурализм приносит стране пользу.

Таким образом, последние десятилетия сопровождаются попытками государств реагировать на многоликость и противоречивость глобального мира. Динамика культурных процессов, размывание границ между различными национальными традициями, высокая динамика иммиграционных процессов привели к обоснованию, а затем и введению в ряде развитых государств политики мультикультурализма. Это свидетельствует о том, что категория «культура» постепенно приходит на смену категориям «национальность», «этничность». Мультикультурализм признаёт ценность культурного плюрализма, уместность и значимость разнообразия и разноликости культурных 
форм. В 70-х гг. XX столетия Австралия объявила мультикультурализм основой своей государственной национальной политики, причём он органично вписался в государственную и общественную жизнь страны. Основой мультикультурализма в Австралии стала интенсивная иммиграция. В середине $\mathrm{XX}$ в. страна столкнулась с серьёзными демографическими проблемами, решить которые удалось посредством привлечения значительного числа иммигрантов. Вплоть до 70-х гг. XX в. проводилась политика «Белой Австралии», которая определяла и иммиграционное законодательство - оно носило дискриминационный характер и основной своей целью имело поощрение въезда в страну европейцев. Международные обязательства Австралии, а также возросшее этническое и культурное разнообразие общества обусловили либерализацию законодательства, в том числе и иммиграционного. После официального утверждения мультикультурализма в качестве государственной политики были созданы, а впоследствии не раз реформировались государственные органы, ответственные за его поддержание и развитие. Значительную помощь им оказывают общественные объединения и другие институты гражданского общества. Опросы общественного мнения показывают, что основная часть австралийцев довольна политикой мультикультурализма и оценивает её как одно из главных преимуществ своей страны.

Можно сделать вывод о том, что австралийский мультикультурализм прошёл три основные стадии развития: а) начальную стадию, для которой характерно идеологическое обоснование необходимости поощрения в обществе культурного и этнического разнообразия; б) стадию становления, которая сопровождается созданием нормативной правовой базы, необходимой для ликвидации всех форм дискриминации и достижения в обществе социальной справедливости при равных возможностях для всех граждан; в) стадию институционализации, на которой создаются органы государственной власти (как правило, исполнительные), ответственные за проведение политики мультикультурализма. Однако очевидно, что универсальной стратегии мультикультурализма не существует, причём не только по географическим, экономическим, политическим и социальным причинам, но и в силу различных ценностных установок государств. Тем не менее, опыт Австралии имеет общечеловеческую ценность, поскольку политика мультикультурализма всегда основывается на непреходящих демократических ценностях и направлена на противостояние дискриминации, нетерпимости и угнетению, поддерживает индивидуальное достоинство людей, обеспечивает в обществе климат доверия. 
Условием успешного проведения политики мультикультурализма являются не только своевременные и эффективные государственные усилия, но и зрелость гражданского общества, заинтересованность населения страны в признании ценности культурного разнообразия и сохранении этнокультурных традиций. Предметом пристального изучения российского научного юридического сообщества, а также юристов-практиков должно стать австралийское миграционное законодательство, направленное на привлечение в страну квалифицированных трудовых кадров, а также опыт Австралии по адаптации иммигрантов в новом для них обществе. Интерес для современной России представляет и процесс формирование австралийцами единой гражданской идентичности, которая не входит в противоречие с национальным самочувствием отдельных групп населения, что весьма актуально в свете разворачивающейся у нас в стране дискуссии об использовании термина «российская нация».

$$
\text { *** }
$$

1. Евреи, конфуцианцы и протестанты. Культурный капитал и конец мультикультурализма / Лоуренс Харрисон; пер. с англ. Ю. Кузнецова. М., 2014.

2. Платошина В.В. Проблема мультикультурализма в эпоху глобализации // Позиция. Философские проблемы науки и техники. 2013. № 7 (7).

3. Шапаров А.Е. От «Белой Австралии» до мультикультурализма // Мировая экономика и международные отношения. 2010. № 3.

4. Australia as a Multicultural Society - Submission to the Australian Population and Immigration Council on the Green paper, Immigration Policies and Australia's Population. - Canberra, 1977.

5. Australian Government. Department of Social Services. Fact Sheet - Australia's Multicultural Policy // URL: https://www.dss.gov.au/our-responsibilities/settlement-and-multiculturalaffairs/publications/fact-sheet-australias-multicultural-policy

6. Birrell R. A New Era in Australian Migration Policy // Interna-tional Migration Review. 1984. V. 18. № 1 .

7. Gaze B. Has the Racial Discrimination Act Contributed to Eliminating Racial Discrimination? Analyzing the Litigation Track Record 2000-2004 // Australian Journal of Human Rights. № 6.

8. Gaze B. The Racial Discrimination Act after 40 years: Advancing equality or sliding into obsolescence? Paper to «RDA@40» Conference on 40 Years of the Racial Discrimination Act, Australian Human Rights Commission. - Sydney, 2015.

9. Grassby A. A Multi-cultural Society for the Future. - Canberra, 1973.

10. Markus A. Mapping Social Cohesion National Report. - Mel-bourne, 2015.

11. Multicultural Australia: United, Strong, Successful. Australia's Multicultural Statement. // URL: https://www.dss.gov.au/sites/default/files/documents/03_2017/multicultural_policy_2017.pdf

12. Tavan G. The Long, Slow Death of White Australia. - Mel-bourne, 2005.

13. Thornton M. The Liberal Promise: Anti-Discrimination Legislation in Australia. - Melbourne. 1990.

14. Whitlam G. Proclamation of the Racial Discrimination Act. Speech // Making Multicultural Australia. 31 October 1975. 